\title{
PROFIL GAYA HIDUP DAN TEKANAN DARAH PENDUDUK DEWASA DI WILAYAH KERJA PUSKESMAS KAMONJI PALU PADA TAHUN 2018
}

\author{
Ida Ayu Putri Herdayanti ${ }^{1}$, Indriani ${ }^{1 *}$ \\ ${ }^{1}$ Program Studi Pendidikan Dokter, Fakultas Kedokteran Universitas Alkhairat, Jl. Diponegoro No. 39 \\ Palu 94221, Sulawesi Tengah, Indonesia \\ "Corresponding author: Telp: +6285292901002 email: Sidney_1484@yahoo.co.id
}

\begin{abstract}
ABSTRAK
Gangguan tekanan darah merupakan penyakit yang masih banyak ditemukan di Indonesia dan di Kota Palu, khususnya di Wilayah Kerja Puskesmas Kamonji Palu. Gangguan tekanan darah bisa terjadi pada usia lanjut dan dapat pula dipengaruhi oleh gaya hidup seseorang. Tujuan penelitian ini adalah untuk mengetahui profil gaya hidup dan tekanan darah pada penduduk dewasa di Wilayah Kerja Puskesmas Kamonji Palu tahun 2018. Penelitian ini merupakan penelitian deskriptif dan analitik dengan design Cross sectional di wilayah kerja Puskesmas Kamonji, dilakukan sejak April sampai Juli tahun 2018. Pengumpulan data dilakukan dengan pengukuran tekanan darah beserta wawancara menggunakan kuesioner. Analisis data menggunakan SPSS 24 untuk mengetahui gambaran gaya hidup dan tekanan darah dengan uji frekuensi dan uji korelasi spearman. Dari 245 penduduk dewasa di Wilayah kerja puskesmas Kamonji Palu pada tahun 2018 diperoleh hasil sebagai berikut : (1) Tekanan darah terbanyak adalah tekanan darah normal sebanyak 139 responden $(56,7 \%)$. (2) tekanan darah berdasarkan kebiasaan merokok terbanyak adalah pada responden yang tidak merokok dengan tekanan darah normal sebanyak 101 responden $(72,7 \%)$, tekanan darah rendah sebanyak 21 responden $(77,8 \%)$, dan tekanan darah tinggi sebanyak 12 responden (15,2\%). (3) tekanan darah berdasarkan kebiasaan mengkonsumsi alkohol terbanyak adalah non alkoholik dengan tekanan darah normal sebanyak 118 responden (84,9\%), tekanan darah rendah sebanyak 25 responden $(92,6 \%)$, dan tekanan darah tinggi sebanyak 43 responden $(54,4 \%)$. (4) aktivitas fisik terbanyak adalah aktivitas fisik sedang dengan tekanan darah normal sebanyak 71 responden $(51,1 \%)$, tekanan darah rendah 2 responden (7,4\%), dan tekanan darah tinggi 36 responden (45,6\%). Kesimpulan penelitian ini yakni Penduduk dewasa di Wilayah kerja puskesmas Kamonji Palu pada tahun 2018 dominan memiliki tekanan darah normal. Adapun responden yang memiliki gaya hidup berupa aktivitas kebiasaan merokok, kebiasaan konsumsi alkohol dan kebiasaan aktifitas fisik dapat mengalami gangguan tekanan darah.
\end{abstract}

Kata Kunci : Gaya hidup, tekanan darah, aktifitas fisik.

\section{ABSTRACT}

Blood pressure disorder is a disease that is still commonly found in Indonesia and in the City of Palu, especially in the Kamonji Palu Health Center Working Area. Blood pressure disorders can occur in old age and can also be influenced by one's lifestyle. The purpose of this study is to determine lifestyle profiles and blood pressure in adult residents in the Kamonji Palu Health Center Working Area in 2018. This study was a descriptive and analytical study with a cross sectional design in the working area of the Kamonji Health Center, conducted from April to July 2018. The data collection was done by measuring blood pressure along with interviews using a questionnaire. Data analysis using SPSS 24 to determine the description of lifestyle and blood pressure by frequency test and spearman correlation test. From the 245 adult residents in the working area of the Kamonji Palu health center in 2018 the following results were obtained: (1) The most blood pressure was normal blood pressure of 139 respondents (56.7\%). (2) blood pressure based on most smoking habits is non-smoking respondents with normal blood pressure of 101 respondents (72.7\%), low blood pressure of 21 respondents (77.8\%), and high blood pressure of 12 respondents ( 15.2\%). (3) blood pressure based on most alcohol consumption habits is non-alcoholic with normal blood pressure of 118 respondents (84.9\%), low blood pressure of 25 respondents (92.6\%), andhigh blood pressure of 43 respondents (54, 4\%). (4) most physical activity is moderate physical activity with normal blood pressure of 71 respondents (51.1\%), low blood pressure 2 respondents (7.4\%), 
and high blood pressure 36 respondents (45.6\%). The conclusion of this study is that the adult population in the working area of the Kamonji health center in Palu in 2018 predominantly had normal blood pressure. The respondents who have a lifestyle such as smoking activities, alcohol consumption habits and physical activity habits can experience blood pressure disorders.

Keywords: Lifestyle, blood pressure, physical activity

\section{PENDAHULUAN}

Gaya hidup adalah cara hidup atau hal yang biasanya dilakukan seseorang dilingkungannya. kebiasaan olah raga, kebiasaan merokok dan kebiasaan minum alkohol yang dapat mempengaruhi tekanan darah seseorang. Tekanan darah adalah tekanan yang ditimbulkan pada dinding arteri. Tekanan darah biasanya digambarkan sebagai rasio tekanan sistolik terhadap tekanan diastolik dengan nilai normal pada dewasa berkisar dari 100/60 sampai 140/90. Tekanan darah terdiri dari tekanan darah rendah, tekanan darah normal, dan tekanan darah tinggi. $1,2,3$

Prevalensi aktifitas fisik menurut WHO pada tahun 2015 adalah $51,5 \%$ dan pada tahun 2014 di Scotlandia adalah 73,6\%. Sedangkan prevalensi aktivitas fisik atau kebiasaan olaraga di Indonesia pada tahun 2007 terdapat 48,2\% yang kurang melakukan aktivitas fisik sedangkan pada tahun 2016 di Palu 1.953 jiwa yang tidak melakukan aktivitas fisik. WHO memperkirakan pecandu alkohol diseluruh dunia mencapai 775ribu jiwa, sedangkan di Indonesia menurut Riskesdas 2007 adalah 4,6\%. Untuk di Sulawesi Tengah terdapat $16,1 \%$ pada tahun 2007. ${ }^{4,5}$

Insidens kebiasaan merokok menurut GTSS pada tahun $201560 \%$ pada pria dan $20 \%$ pada wanita. Prevalensi kebiasaan merokok di Indonesia pada tahun 2015 terdapat $65 \%$ pada pria dan $5 \%$ pada wanita. Pada tahun 2016 di kota palu terdapat 2000 jiwa yang merokok. Insidensi hipertensi menurut WHO pada tahun 2017 terdapat 600 juta penderita sedangkan prevalensi di Indonesia sesuai dengan data Riskesdas pada tahun 2013 sebesar $25,8 \%$ dan untuk Sulawesi Tengah pada tahun 2013 sebesar 30\%. Dan insidensi di Puskesmas Kamonji pada tahun 20173369 orang. ${ }^{6,7,8}$

Kebiasaan olah raga, kebiasaan merokok dan kebiasaan mengkonsumsi alkohol merupakan gaya hidup yang berpengaruh pada tekanan darah. Berhenti merokok, melakukan olah raga dan tidak konsumsi alkohol merupakan cara untuk menjaga dan meningkatkan kualitas kesehatan seseorang, dan menghindari komplikasi yang terjadi terutama pada perubahan tekanan darah. $^{9}$

Gangguan tekanan darah merupakan penyakit yang masih banyak ditemukan di Indonesia dan di Kota Palu, khususnya di Wilayah Kerja Puskesmas Kamonji. Gangguan tekanan darah bisa terjadi pada usia lanjut dan dapat pula dipengaruhi oleh gaya hidup seseorang. Oleh karena itu hasil penelitian ini akan menjadi masukan sebagai bahan promosi kesehatan khususnya untuk pencegahan terjadinya gangguan pada tekanan darah.

\section{METODOLOGI}

Jenis penelitian yang digunakan adalah deskriptif kategorik. Dengan desain penelitian cross sectional. Penelitian dilakukan pada bulan April s/d Juli tahun 2018. Tempat penelitian yaitu di wilayah kerja Puskesmas Kamonji Palu. Populasi penelitian adalah semua penduduk dewasa yang berada di wilayah kerja Puskesmas Kamonji Palu pada tahun 2018.

Subyek penelitian adalah semua penduduk dewasa yang berada di wilayah kerja Puskesmas Kamonji di Kelurahan Siranindi Palu pada tahun 2018 yang memenuhi kriteria penelitian. Kriteria Inklusi penelitian adalah penduduk dewasa di wilayah kerja puskesmas kamonji di Kelurahan Siranindi Palu, perempuan dan laki-laki yang berusia 26-45 tahun dan bersedia mengikuti penelitian secara sukarela tanpa ada paksaan dari pihak manapun. Kriteria Eksklusi penelitian adalah responden yang tidak dapat berkomunikasi, responden sedang dalam masa pengobatan penyakit tertentu, responden yang mengalami gangguan metabolik atau penyakit kronis seperti penyakit jantung, diabetes, dan gagal ginjal. 
Metode pengambilan sampel menggunakan cara cluster random sampling. Besar sampel yang dibutuhkan adalah 245 orang.

Instrumen dan alat yang digunakan menggunakan formulir kuisioner IPAQ yang telah dimodifikasi, kuisioner mengenai kebiasaan merokok dan alat pengukuran tekanan darah yaitu sphygmomanometer GEA dan Stetoskop Litman.

Analisa data yang digunakan menggunakan perangkat lunak komputer program SPSS 24.0. Adapun analisis data menggunakan uji frekuensi berdasarkan tiap variabel yang diteliti.

\section{HASIL DAN PEMBAHASAN}

Data yang diperoleh terdiri dari tekanan darah hipotensi, normotensi dan hipertensi aktivitas fisik yang digolongkan menjadi tinggi, sedang dan rendah, kebiasaan merokok digolongkan menjadi tidak merokok, ringan, dan berat. Kebiasaan minum alkohol digolongkan menjadi alkoholik dan non alkoholik Hasil analisa statistik ditampilkan dengan sistematika sebagai berikut.

Tabel 1. Karakteristik sampel berdasarkan umur dan jenis kelamin

\begin{tabular}{lcc}
\hline \multicolumn{1}{c}{ Variabel } & $\begin{array}{c}\text { Jumlah } \\
(\mathrm{N})\end{array}$ & $\begin{array}{c}\text { Persentase } \\
(\%)\end{array}$ \\
\hline 1. Umur & & \\
a. Dewasa awal & 88 & 35,9 \\
$\quad(26-35)$ & 157 & 64,1 \\
b. Dewasa akhir & & \\
$\quad(36-45)$ & & \\
\hline 2. Jenis kelamin & & \\
a. Laki-laki & 95 & 38,8 \\
b. Perempuan & 150 & 61,2 \\
\hline
\end{tabular}

Berdasarkan tabel 1 diperoleh persentase yang berusia dewasa awal ( 26 - 35 tahun) sebanyak 88 orang $(35,9 \%)$ dan yang berusia dewasa akhir (36 - 45 tahun) sebanyak 157 orang $(64,1 \%)$. Sampel dengan jenis kelamin laki - laki yaitu sebanyak 95 orang $(38,8 \%)$, dan jenis kelamin perempuan yaitu sebanyak 150 orang $(61,2 \%)$.
Tabel 2. Profil tekanan darah pada penduduk dewasa di wilayah kerja Puskesmas Kamonji Palu pada tahun 2018.

\begin{tabular}{ccc}
\hline Tekanan darah & $\mathrm{N}$ & $\%$ \\
\hline Hipotensi $<90 / 90$ & 27 & 11,0 \\
mmHg & 139 & 56,7 \\
Normotensi & 79 & 32,2 \\
$<120 / 80 \mathrm{mmHg}$ & & \\
Hipertensi $>130 / 80$ & & \\
mmHg & & \\
\hline Total & 245 & $100 \%$ \\
\hline
\end{tabular}

Berdasarkan tabel 2 yang memiliki tekanan darah rendah (Hipotensi) sebanyak 27 orang (11,0\%), tekanan darah normal (normotensi) sebanyak 139 (56,7\%) dan yang memiliki tekanan darah tinggi (Hipertensi) sebanyak $79(32,2 \%)$.

Tabel 3. Gambaran kebiasaan merokok penduduk dewasa di wilayah kerja Puskesmas Kamonji Palu tahun 2018.

\begin{tabular}{|l|c|c|}
\hline $\begin{array}{c}\text { Kebiasaan } \\
\text { merokok }\end{array}$ & $\mathrm{N}$ & $\%$ \\
\hline Tidak merokok & 134 & 54,7 \\
\hline Ringan & 10 & 4,1 \\
\hline Berat & 101 & 41,2 \\
\hline Total & 245 & 100 \\
\hline
\end{tabular}

Berdasarkan tabel 3 yang tidak memiliki kebiasaan merokok sebanyak 134 orang $(54,7 \%)$, kebiasaan merokok ringan sebanyak 10 orang $(4,1 \%)$ dan subyek kebiasaan merokok yang berat sebanyak 101 orang $(41,2 \%)$.

Tabel 4. Gambaran kebiasaan minum alkohol penduduk dewasa di wilayah kerja Puskesmas Kamonji Palu tahun 2018.

\begin{tabular}{lcc}
\hline $\begin{array}{c}\text { Kebiasaan minum } \\
\text { alkohol }\end{array}$ & $\mathrm{N}$ & $\%$ \\
\hline Alkoholik & 59 & 24,1 \\
Non alkoholik & 186 & 75,9 \\
\hline Total & 245 & 100
\end{tabular}

Tabel 4 menunjukkan yang memiliki kebiasaan minum alkohol 59 orang $(24,1 \%)$, dan subyek yang non alkoholik $186(75,9 \%)$. 
Tabel 5. Gambaran aktivitas fisik penduduk dewasa di wilayah kerja Puskesmas Kamonji Palu tahun 2018.

\begin{tabular}{ccc}
\hline Aktivitas Fisik & $\mathrm{N}$ & $\%$ \\
\hline Tinggi & 86 & 35,1 \\
Sedang & 109 & 44,5 \\
Rendah & 50 & 20,4 \\
\hline Total & 245 & 100 \\
\hline
\end{tabular}

Tabel 5 menunjukkan yang memiliki aktifitas fisik tinggi 86 orang $(35,1 \%)$, aktivitas fisiknya sedang $109(44,5 \%)$ dan subjek yang aktivitas fisiknya rendah $50(20,4 \%)$.

Tabel 6. Gambaran kebiasaan merokok berdasarkan tekanan darah

\begin{tabular}{|c|c|c|c|c|}
\hline \multirow{2}{*}{$\begin{array}{c}\text { Kebiasaan } \\
\text { merokok }\end{array}$} & \multicolumn{3}{|c|}{ Tekanan darah } & \multirow{2}{*}{ Total } \\
\cline { 2 - 4 } & Hipotensi & Normotensi & Hipertensi & \\
\cline { 2 - 4 } & $\mathrm{N}(\%)$ & $\mathrm{N}(\%)$ & $\mathrm{N}(\%)$ & \\
\hline Tidak merokok & 21 & 1 & 12 & 134 \\
& $(77,8 \%)$ & $(72,7 \%)$ & $(15,2 \%)$ & $(54,7 \%)$ \\
\hline Ringan & 0 & 10 & 0 & 10 \\
& $(0,0 \%)$ & $(7,2 \%)$ & $(0,0 \%)$ & $(4,1 \%)$ \\
\hline Berat & 6 & 28 & 67 & 101 \\
\hline & $(19,4 \%)$ & $(18,8 \%)$ & $(84,8 \%)$ & $(41,2 \%)$ \\
\hline Total & 27 & 139 & 79 & 245 \\
& $(100,0 \%)$ & $(100,0 \%)$ & $(100,0 \%)$ & $(100,0)$ \\
\hline
\end{tabular}

Tabel 7. Gambaran kebiasaan alkohol berdasarkan tekanan darah

\begin{tabular}{|c|c|c|c|c|}
\hline \multirow{2}{*}{$\begin{array}{c}\text { Kebiasaan minum } \\
\text { alkohol }\end{array}$} & \multicolumn{3}{|c|}{ Tekanan darah } & \multirow{2}{*}{ Total } \\
\cline { 2 - 4 } & Hipotensi & Normotensi & Hipertensi & \\
\cline { 2 - 4 } & $\mathrm{N}(\%)$ & $\mathrm{N}(\%)$ & $\mathrm{N}(\%)$ & \\
\hline Alkoholik & 2 & 21 & 36 & 59 \\
& $(7,4 \%)$ & $(15,1 \%)$ & $(45,6 \%)$ & $(24,1 \%)$ \\
\hline Non alkoholik & 25 & 118 & 43 & 186 \\
& $(92,6 \%)$ & $(84,9 \%)$ & $(54,4 \%)$ & $(75,9 \%)$ \\
\hline Total & 27 & 139 & 79 & 245 \\
& $(100,0 \%)$ & $(100,0 \%)$ & $(100,0 \%)$ & $(100,0 \%)$ \\
\hline
\end{tabular}

Tabel 8. Gambaran antara aktivitas fisik berdasarkan tekanan darah

\begin{tabular}{ccccc}
\hline & \multicolumn{3}{c}{ Tekanan darah } & \\
\cline { 2 - 4 } Aktivitas Fisik & Hipotensi & Normotensi & Hipertensi & \multirow{2}{*}{ Total } \\
\cline { 2 - 4 } & $\mathrm{N}(\%)$ & $\mathrm{N}(\%)$ & $\mathrm{N}(\%)$ & \\
\hline Tinggi & 24 & 43 & 19 & 86 \\
& $(88,9 \%)$ & $(30,9 \%)$ & $(24,1 \%)$ & $(35,1 \%)$ \\
\cline { 2 - 4 } Sedang & 2 & 71 & 36 & 109 \\
& $(7,4 \%)$ & $(51,1 \%)$ & $(45,6 \%)$ & $(44,5 \%)$ \\
\cline { 2 - 4 } Rendah & 1 & 25 & 24 & 50 \\
& $(3,7 \%)$ & $(18,0 \%)$ & $(30,4 \%)$ & $(20,4 \%)$ \\
Total & 27 & 139 & 79 & 245 \\
& $(100,0 \%)$ & $(100,0 \%)$ & $(100,0 \%)$ & $(100,0 \%)$ \\
\hline
\end{tabular}


Gambaran tekanan darah penduduk dewasa di wilayah kerja Puskesmas Kamonji Palu tahun 2018.

Hasil penelitian gambaran tekanan darah penduduk dewasa di wilayah kerja Puskesmas Kamonji Palu, menunjukkan hasil yang terbanyak adalah penduduk dengan tekanan darah yang tergolong normal (Normotensi) yaitu sebanyak 139 orang (56,7\%). Kemudian tekanan darah yang tergolong tinggi (Hipertensi) yaitu sebanyak 79 (32,2\%) dan terakhir adalah penduduk yang tergolong tekanan darah rendah (Hipotensi) sebanyak 27 orang $(11,0)$. Yang memiliki tekanan darah tinggi di wilayah kerja puskesmas kamonji palu masih sangat banyak, hal ini dikarenakan pengaruh gaya hidup dan faktor makanan yang tidak terkontrol. selain itu petugas kesehatan juga diharapkan untuk meningkatkan melakukan screening atau deteksi dini tekanan darah tinggi pada masyarakat, dan memberikan penyuluhan tentang hipertensi dan gaya hidup sehat. Penelitian ini sejalan dengan yang dilakukan oleh Sitti Fatmawati tahun 2017 di Wilayah kerja Puskesmas Puuwatu Kendari yang menyatakan bahwa lebih banyak penduduk dewasa memiliki tekanan darah yang normal yaitu sebesar 63,8 $\%^{3}$

Gambaran kebiasaan merokok penduduk dewasa di wilayah kerja Puskesmas Kamonji Palu tahun 2018.

Hasil penelitian gambaran kebiasaan merokok penduduk dewasa di wilayah kerja Puskesmas Kamonji Palu didapatkan hasil sebagian besar penduduk tidak merokok yaitu sebanyak 134 orang $(54,7 \%)$, penduduk yang dikategorikan sebagai perokok ringan sebanyak 10 orang $(4,1 \%)$, dan yang dikategorikan perokok berat sebanyak 101 orang $(41,2 \%)$.

Gambaran kebiasaan minum alkohol penduduk dewasa di wilayah kerja Puskesmas Kamonji Palu tahun 2018.

Hasil penelitian gambaran kebiasaan minum alkohol penduduk dewasa di wilayah kerja Puskesmas Kamonji Palu didapatkan hasil sebagian besar penduduk yang tidak mengkonsumsi alkohol atau non alkoholik yaitu sebanyak 186 (75,9\%), dan penduduk yang dikategorikan sebagai alkoholik sebanyak 59 orang $(24,1 \%)$.

Gambaran aktivitas fisik penduduk dewasa diwilayah kerja Puskesmas Kamonji Palu tahun 2018.

Hasil penelitian gambaran aktivitas fisik penduduk dewasa di wilayah kerja Puskesmas Kamonji Palu, didapatkan tingkat aktivitas fisik yang sedang merupakan jumlah yang terbanyak yaitu 109 orang (44,5\%), kemudian yang memiliki aktivitas fisik tinggi sebanyak 86 orang $(35,1 \%)$, dan yang terendah adalah penduduk dengan aktivitas yang rendah yaitu sebanyak 50 orang $(20,4 \%)$. Hal Ini dikarenakan penduduk dewasa di wilayah kerja puskesmas Kamonji dominan memiliki pekerjaan sebagai pekerja kantoran.

Gambaran antara kebiasaan merokok berdasarkan tekanan darah penduduk dewasa di wilayah kerja puskesmas Kamonji palu tahun 2018.

Berdasarkan penelitian kebiasaan merokok, responden yang tidak merokok sebagian besar normotensi sebanyak 101 $(72,7)$ dan responden perokok berat memiliki tekanan darah hipertensi sebanyak $67(84,8)$. Hal ini akibat adanya faktor stress yang dikarenakan banyaknya pekerjaan sehingga mereka mengalihkan dengan merokok, maka sebagian penduduk dewasa di wilayah kerja puskesmas Kamonji Palu menghilangkan stress dengan cara merokok dan selain itu kurangnya penyuluhan mengenai bahaya merokok terhadap kesehatan. Hal ini sejalan dengan Penilitian yang dilakukan oleh Angela novalia tahun 2012 di Semarang yang menyatakan bahwa responden yang merupakan perokok berat sebagian besar mengalami hipertensi yaitu sebanyak 92,3\%. Kebiasaan ini sulit untuk dihentikan. Nikotin dalam tembakau adalah penyebab meningkatnya tekanan darah. Merokok dapat menyebabkan kelainan struktur jaringan yang berkaitan erat dengan respon inflamasi yang ditimbulkan oleh partikel atau gas beracun dari rokok. Semakin banyak jumlah batang rokok 
yang dihisap dan makin lama masa waktu menjadi perokok, sebagian besar resiko dapat mengalami tekanan darah meningkat. ${ }^{10}$

Gambaran antara kebiasaan minum alkohol dengan tekanan darah penduduk dewasa di Wilayah kerja puskesmas Kamonji Palu tahun 2018.

Berdasarkan penelitian kebiasan mengkonsumsi alkohol di dapatkan hasil responden yang memiliki kebiasaan mengkonsumsi alkohol sebagian besar hipertensi yaitu sebanyak 36 responden $(45,6 \%)$, sedangkan responden yang tidak memgkonsumsi alkohol sebagian besar tekanan darahnya normal (normotensi) yaitu sebanyak 118 responden $(84,9 \%)$. Hal ini sejalan dengan hasil penelitian dari Monica ruus tahun 2016 di Kabupaten Minahasa Selatan. Didapatkan hasil kebanyakan responden yang mengkonsumsi alkohol memiliki tekanan darah tinggi (hipertensi) sebanyak 33 responden. Adapun faktor yang membuat sebagian penduduk di wilayah kerja puskesmas Kamonji Palu masih mengkonsumsi alkohol atau dikatakan alkoholik karena faktor lingkungan, stress, sebagai pelarian mereka dengan mengkonsumsi alkohol, faktor pergaulan, dan gaya hidup yang kurang sehat. ${ }^{11}$

Konsumsi alkohol menyebabkan peningkatan angiotensin II, sebuah vasokonstriktor kuat yang akan mengakibatkan tekanan darah sistemik, meningkatkan kecepatan aliran darah ke ginjal sehingga perfusi ginjal meningkat. Angiotensin II juga merangsang korteks adrenal untuk mengeluarkan aldosteron, suatu hormon yang mempercepat absorbsi garam dan air yang berdampak pada peningkatan tekanan darah. ${ }^{12,13}$

Gambaran antara aktivitas fisik dengan tekanan darah pada penduduk dewasa di Wilayah kerja puskesmas Kamonji palu tahun 2018.

Hasil penelitian tekanan darah, berdasarkan aktivitas fisik didapatkan penduduk dewasa dengan aktivitas tinggi kebanyakan memiliki tekanan darah yang normal (normotensi yaitu sebanyak 43 responden $(30,9 \%)$, aktivitas sedang sebagian besar normotensi yaitu sebanyak 71 responden $(51,1 \%)$ dan yang aktivitas fisik rendah sebagian besar memiiki tekanan darah hipertensi sebanyak 24 responden $(30,4 \%)$. Dimana penduduk dewasa di wilayah kerja puskesmas kamonji palu lebih banyak melakukan aktifitas ditempat kerja dan tidak melakukan aktifitas tambahan misalnya berolah raga. Hal ini tidak sejalan dengan penelitian yang dilakukan oleh Marina Mila tahun 2016 di Yogyakarta yang menyatakan bahwa sebagian besar responden dengan aktivitas fisik rendah memiliki tekanan darah hipertensi sebanyak $83,3 \% .^{14}$

Kurangnya aktivitas fisik meningkatkan resiko menderita hipertensi karena meningkatkan resiko kelebihan berat badan orang yang tidak aktiv juga cenderung mempunyai frekuensi denyut jantung yang lebih tinggi sehingga otot jantungnya bekerja lebih keras pada setiap kontraksi. Makin keras dan sering otot jantung harus memompa, makin besar tekanan yang dibebankan tekanan pada arteri yang kemudian menunjukan gambaran hipertensi.

\section{DAFTAR PUSTAKA}

1. Natalia et al. 2014."Tata Lakasana Terkini pada Hipertensi Tinjauan Pustaka," vol. 20, no. 52, pp. 36-41.

2. Joint and N. Commite. 2016, "Evidencebased Guideline Penanganan Pasien Hipertensi Dewasa,' vol. 43, no. 1, pp. 5459.

3. Sitti Fatmawati, et al. 2017. Hubungan Life Style dengan kejadian Hipertensi pada usia dewasa (20-44 tahun) di Wlayah kerja Puskesmas Puuwatu Kota Kendari.

4. World Health Organization (WHO). 2015. World Health Statistics. WHO Library Cataloguing in Publication Data, Geneva. p. 110-111.

5. Riskesdas. 2007. Preferensi peminum alkohol di Indonesia. Departemen Kesehatan, Republik Indonesia.

6. Asma S, Mackay J, Song YS, et.al. 2015. Global Tobacco Surveillancce System: The 
GATS Atlas. CDC Foundation, Atlanta.

7. Dinas Kesehatan Provinsi Sulawesi Tengah. 2016. Data Faktor Resiko Penyakit tidak menular di Stulawesi Tengah.

8. WHO. 2017. Global Strategy on Diet, Physical Activity and Health.

9. Utama A. Hubungan Antara Aktivitas Fisik dengan Profil Tekanan Darah pada Pria Dewasa di Wilayah Kerja Puskesmas Pantoloan, Tahun 2016. Skripsi tidak diterbitkan. Palu: PSPD Fakultas Kedokteran Unisa.

10. Angela Novalia. 2012. Hubungan antara kebiasaan merokok dengan tekanan darah meningkat karyawan laki-laki di Nasmuko Semarang. p241-250.

11. Monica Ruus, et al. 2016. Hubungan antara konsumsi alkohol dan kopi dengan kejadian hipertensi pada laki-laki di desa Ongkaw Dua Kec. Sinonsayang Kab Minahasa Selatan.

12. Sofyan, Sihombing I. Y., and Y. HAMRA. 2013. "Hubungan Umur, Jenis, Kelamin, dan Hipertensi dengan kejadian Stroke," Medula, vol. 1, no. 1, pp. 24-30.

13. Setyanda, G.o.Y., Sulastri, D., Lestari. 2015. "Artikel Penelitian Hubungan Merokok dengan kejadian Hipertensi pada laki-laki Usia 36-35 Tahun di kota Padang, “ vol. 4, no. 2, pp. 434-440. J. Kesehat. Andalas.

14. Marina Mila, et al. 2016. Hubungan aktifitas fisik dengan tekanan darah pada lansia di dusun Miri desa Sriharjo Imogiri Bantul Yogyakarta. 